\title{
Statistical Models to Predict the Height of Trees and Yield of Field Crop in the Agroforestry System
}

\author{
R. Veena*, S.N. Megeri*, and S.J. Patil \\ Department of Agricultural Statistics, University of Agricultural Sciences, \\ Dharwad - 580005, Karnataka, India \\ *Corresponding author
}

\section{A B S T R A C T}

In this investigation an effort is made to fit a model for the height of different tree species

\section{Keywords}

Morgan-Mercer-Flodin (MMF), Gompertz, Weibull, Sinusoidal, Hoerl, Rational etc.

Article Info

Accepted:

24 August 2018

Available Online:

10 September 2018 and the yield of field crop. Here we have considered three trees species namely Ceiba pentandra, Terminalia bellarica, Mangifera indicia and soybean as field crop. The required data was collected from AICRP on agroforestry, UAS Dharwad. The different models were tried and the best two models were selected based on $\mathrm{R}^{2}$ and Standard error values. The best fitted models for height of Ceiba pentandra, Terminalia bellarica and Mangifera indicia were MMF model followed by Gompertz relation, MMF model followed by Weibull model and MMF model followed by polynomial. The results indicated that MMF model was found better for all the tree species. To predict the yield of field crop (soybean, at $1 \mathrm{~m}$ distance) was increased in the beginning i.e. up to five years and then declining trend was notice. The best fitted models for the yield of soybean were, Rational model followed by Sinusoidal model in case of Ceiba pentandra, Rational model followed by Hoerl model for Terminalia bellarica, and Hoerl model followed by Rational model for Mangifera indicia.

\section{Introduction}

The productive area available in the country is around $300 \mathrm{~m}$. ha of which $76.5 \mathrm{~m}$. ha is recorded forest area. In percentage, India's Forest Cover accounts for $20.6 \%$ of the total geographical area of the country as of 2005. Actual forest cover is 63.34 million ha of which 26.13 million ha is degraded. About 20 million ha is covered under private tree planting (agroforestry, farm forestry, social forestry and other plantations). In order to meet the increasing demand of our fast growing population, we would require to boost the production of food grain, fuel wood and also green and dry fodder for livestock to the tune of $1061 \mathrm{mt}$ and $589 \mathrm{mt}$, respectively, besides 75 million $\mathrm{m}^{3}$ of timber. Thus, to meet the gap between demand and supply of fodder, fuel wood and timber, the emphasis should be on the integration of tree component with agricultural crops, which is precisely agroforestry.

Growth refers to the increase in dimensions of one or more individuals in a forest stand over a given period of time (e.g. volume growth in $\left.\mathrm{m}^{3} / \mathrm{ha} / \mathrm{y}\right)$. Yield refers to their final 
dimensions at the end of a certain period (e.g. volume in $\mathrm{m}^{3} / \mathrm{ha}$ ).

A statistical model is a set of mathematical equations which describes the behaviour of an object of study in terms of random variables and their associated probability distributions.

Modelling the goal of modelling is to understand reality mathematically. A model is considered a simplified representation of reality. Many complex interactions and results are depicted with simplicity to reach a decision. It is expected to be a good representation of those factors that influence production and management. Modeling has been used in natural sciences since centuries in one way or the other. Models have been built in the physical, biological and social sciences.

Various researches have defined modeling in their own way viz.,

"Modeling is described as a representation of our so called 'real world' in mathematical terms", so that we may gain a more precise understanding of its significant properties, and which may hopefully allow some forms of prediction of future events.

Model is reality scaled down and converted to a form we can comprehend.

A mathematical model is a model whose parts are mathematical concepts, such as constants, variables, functions, equations, inequalities etc.

\section{Why we use modelling in agroforestry}

In agro forestry tree component is retained for a long period of time (say 8 to 35 years or more). Now to develop growth and yield models, one has to harvest trees at different intervals to get a complete range of data. It amounts to say that we will have to wait for years together to get the growth / yield information of the tree component. However, using the modelling tools we can predict the growth / yield of the tree component at a very early stage.

\section{Materials and Methods}

\section{Description of study area}

The experimental site is situated in Farm forestry unit, University of Agricultural Sciences, Dharwad. Dharwad is situated in Northern Transition Zone (zone 8) of Karnataka, with a latitude of $15^{0} 26^{1}$ north, a longitude of $75^{\circ} 07^{1}$ east and at an altitude of $678 \mathrm{~m}$ above mean sea level. Total geographic area of Dharwad is 427329 ha. The annual rain fall in this zone is $749.48 \mathrm{~mm}$, major proportion of rainfall was received during June, July, August, September and October with heavy rains in July and September. The highest mean monthly maximum temperature recorded during May was $37.0^{\circ} \mathrm{C}$ which was $0.05^{\circ} \mathrm{C}$ higher as compared to the average maximum temperature of 56 years of same month. The lowest mean monthly temperature was recorded in December $13.1^{\circ} \mathrm{C}$. Relative humidity was higher during June to September. The total number of rainy days (77days) was more than the average of previous 34 years (55.31 days).

\section{Materials}

The data for this study was procured from AICRP (All India Co-Ordinated Research Project on Agroforestry) UAS Dharwad. Experimental data contains information on parameters like grain yield of soybean at different distances from trees, height, dbh, crown area of various tree species of 14 years from 1993-2007 was used for the study. We tried different models such as linear regression model, quadratic model, cubic model, 
logarithmic model, logistic model and exponential models and found that simple linear regression model, quadratic model were best fit based on $\mathrm{R}^{2}$ values and standard error values

\section{MMF model}

The Morgan-Mercer-Flodin family function is nonlinear sigmoid growth functions. The general form of the Morgan-Mercer-Flodin family function (MMF) is

MMF Model: $y=\left(a^{*} b+c^{*} x^{\wedge} d\right) /\left(b+x^{\wedge} d\right)$

Where,

$\mathrm{x}$ is a independent variable.(dbh, height).

$\mathrm{y}$ is a dependent variable (age in years)

Where $a, b, c, \& d$ are the parameters in the model

\section{Gompertz model}

Gompertz Relation: $y=a * \exp (-\exp (b-c x))$

Where

$\mathrm{x}$ is a independent variable.(dbh, height), $\mathrm{y}$ is a dependent variable (age in years), $\mathrm{a} b, \mathrm{c}$ re the parameters in the model

The Gompertz reliability growth model is often used when analyzing reliability data. It is most applicable when the data set follows a smooth curve. The Parameter Estimation for the Gompertz Models can be carried out by Using Least Squares in Nonlinear Regression as well as using linear regression methods.

\section{Weibull model}

Weibull Model: $y=a-b * \exp \left(-c^{*} x^{\wedge} d\right)$

Where $\mathrm{x}$ is a independent variable (dbh, height), $\mathrm{y}$ is a dependent variable (age in years), $\mathrm{a}, \mathrm{b} \mathrm{c}$ and $\mathrm{d}$ are the parameters in the model

\section{Polynomial model}

Polynomial regression is a form of linear regression in which the relationship between the independent variable $x$ and the dependent variable $y$ is modeled as an $n$th order polynomial. Polynomial regression fits a nonlinear relationship between the value of $x$ and the corresponding conditional mean of $y$, denoted $\mathrm{E}(y \mid x)$. In general, we can model the expected value of $y$ as an $n$th order polynomial, yielding the general polynomial regression model,

$y=a_{0}+a_{1} x+a_{2} x^{2}+a_{3} x^{3}+\cdots+a_{n} x^{n}+\varepsilon$.

Where,

$\mathrm{y}$ is dependent variable

$a_{\mathrm{i}}$, are Unknown parameters, $\mathrm{i}=0,1,2 \ldots$,

$x$ is independent variables.

\section{Rational function}

A rational function model is a generalization of the polynomial model. A rational function is basically a division of two polynomial functions. That is, it is a polynomial divided by another polynomial. In formal notation, a rational function would be symbolized like this:

$$
f(x)=\frac{s(x)}{t(x)}
$$

Where $\mathrm{s}(\mathrm{x})$ and $\mathrm{t}(\mathrm{x})$ are polynomial functions, and $t(x)$ cannot equal zero. A rational function is simply the ratio of two polynomial functions.

$y=\frac{a_{n} x^{n}+a_{n-1} x^{n-1}+\ldots+a_{2} x^{2}+a_{1} x+a_{0}}{b_{m} x^{m}+b_{m-1} x^{m-1}+\ldots+b_{2} x^{2}+b_{1} x+b_{0}}$ 
With $n$ denoting a non-negative integer that defines the degree of the numerator and $m$ is a non-negative integer that defines the degree of the denominator. For fitting rational function models, the constant term in the denominator is usually set to 1. Rational functions are typically identified by the degrees of the numerator and denominator.

\section{Sinusoidal model}

The sinusoidal speech model represents a speech signal as a linear combination of Sinusoids with time-varying parameters \{amplitudes, frequencies, and phases\}. A sinusoidal model to approximate a sequence $Y_{i}$ is:

$Y_{i}=C+\alpha \sin \left(\omega T_{i}+\varphi\right)+E_{i}$

Where, $C$ is constant defining a mean level, $\alpha$ is an amplitude for the sine wave,

$\omega$ is the frequency, $T_{i}$ is a time variable, $\varphi$ is the phase, and $E_{i}$ is the error sequence in approximating the sequence $Y_{i}$ by the model.

\section{Results and Discussion}

The best fitted model for the height of the tree species Ceiba pentandra+ soybean, out of different models tried MMF model was proved better with $\left(\mathrm{R}^{2}=0.9731, \mathrm{SE}=35.82\right)$, followed by Gompertz relation with $\left(\mathrm{R}^{2}=0.9721, \quad \mathrm{SE}=37.00\right)$. For the fifth treatment combination Terminalia bellerica+ soybean, out of different models tried MMF model was proved better with $\left(\mathrm{R}^{2}=0.9900\right.$, $\mathrm{SE}=32.85)$, followed by Weibull model $\left(\mathrm{R}^{2}=0.9900, \quad \mathrm{SE}=34.04\right)$. For the sixth treatment combination Mangifera indica+ soybean, out of different models tried MMF model was proved better with $\left(\mathrm{R}^{2}=0.9816\right.$, $\mathrm{SE}=35.37)$, followed by polynomial $\left(\mathrm{R}^{2}=0.9806, \mathrm{SE}=35.85\right)$ (Table 1$)$.

The different models were tried to predicting yield of soybean with treatment combination Ceiba pentandra+ soybean, out of different models tried model Rational function was proved better with $\left(\mathrm{R}^{2}=0.900, \mathrm{SE}=1.965\right)$, followed by Sinusoidal model with $\left(\mathrm{R}^{2}=8.996\right.$, $\mathrm{SE}=1.975)$. For the fifth treatment combination Terminalia bellerica+ soybean, Rational function was proved better with $\left(\mathrm{R}^{2}=0.923\right.$, $\left.\mathrm{SE}=1.529\right)$, followed by Hoerl model $\left(\mathrm{R}^{2}=0.884, \mathrm{SE}=1.796\right)$. For the sixth treatment combination Mangifera indica+ soybean, out of different models tried Hoerl model was proved better with $\left(\mathrm{R}^{2}=0.937\right.$, $\mathrm{SE}=1.933$ ), followed by Rational function $\left(\mathrm{R}^{2}=0.932, \mathrm{SE}=2.66\right)$ (Table 2).

Best suited models with their predicted height values of different tree species for next 6 years and the corresponding increment values.

Table.1 Prediction models for height growth of trees. (10 m x10m spacing, $10 \mathrm{~m}$ between rows and $10 \mathrm{~m}$ between trees)

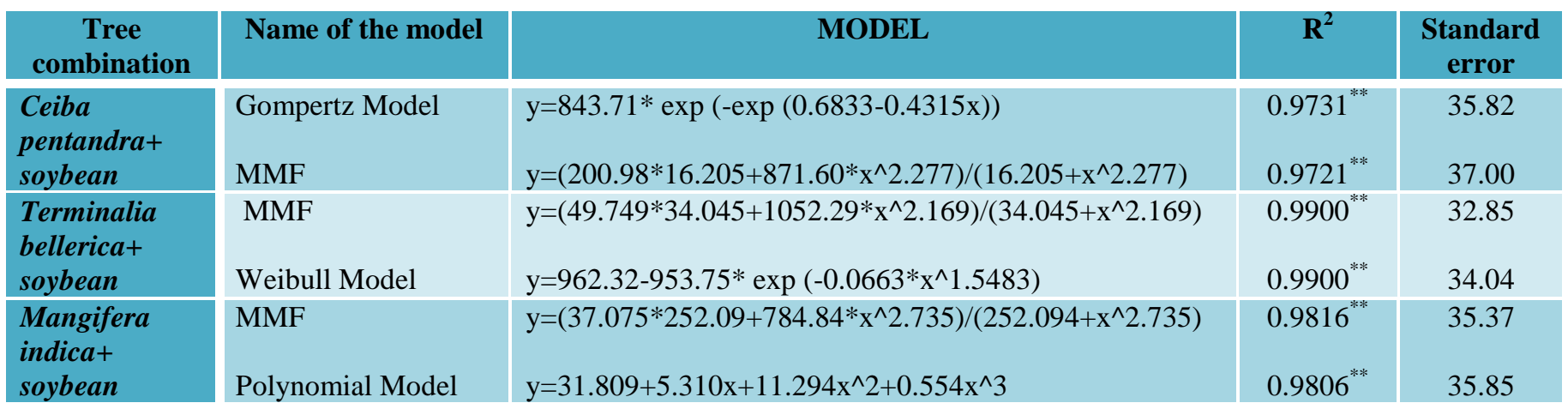


Table.2 Prediction models for yield of soybean crop at one meter distance from trees

\begin{tabular}{l|l|l|l|l|}
\hline \multicolumn{1}{|c|}{ Treatment } & Name of the model & \multicolumn{1}{|c|}{ MODEL } & \multicolumn{1}{c|}{$\mathbf{R}^{2}$} & \multicolumn{1}{c|}{ Treatment } \\
\hline $\begin{array}{l}\text { Ceiba } \\
\text { pentandra+ } \\
\text { soybean }\end{array}$ & Rational function & $\mathrm{y}=(2.914-0.1572 \mathrm{x}) /\left(1-0.2472 \mathrm{x}+0.0172 \mathrm{x}^{2}\right)$ & $0.900^{* *}$ & 1.965 \\
\hline $\begin{array}{l}\text { Terminalia } \\
\text { bellerica+ } \\
\text { soybean }\end{array}$ & Rational function & $\mathrm{y}=(-0.9097+1.68 \mathrm{x}) /\left(1-0.4114 \mathrm{x}+0.063 \mathrm{x}^{2}\right)$ & $8.996^{* *}$ & 1.975 \\
\hline $\begin{array}{l}\text { Mangifera } \\
\text { indica+ } \\
\text { soybean }\end{array}$ & Hoerl model & $\mathrm{y}=3.612^{*}\left(0.558^{\wedge} \mathrm{x}\right) *\left(\mathrm{x}^{\wedge} 2.646\right)$ & $0.923^{* *}$ & 1.529 \\
\hline
\end{tabular}

Table.3 Table shows the best suited models with their predicted height values of different tree species for next 6 years and the corresponding increment values

\begin{tabular}{|c|c|c|c|c|}
\hline $\begin{array}{c}\text { Tree } \\
\text { combination }\end{array}$ & $\begin{array}{l}\text { Model } \\
\text { name }\end{array}$ & model & $\mathrm{X}(\mathrm{yrs})$ & $\mathbf{Y}(\mathrm{cm})$ \\
\hline \multirow{12}{*}{$\begin{array}{l}\text { Ceiba } \\
\text { pentandra+ } \\
\text { soybean }\end{array}$} & Gompertz & $y=843.71 * \exp (-\exp (0.6833-0.4315 x))$ & 15 & 823.74 \\
\hline & Model & & 16 & 846.69 \\
\hline & & & 17 & 865.54 \\
\hline & & & 18 & 880.93 \\
\hline & & & 19 & 893.45 \\
\hline & & & 20 & 903.61 \\
\hline & MMF & $\mathrm{y}=\left(200.98 * 16.205+871.60 * x^{\wedge} 2.277\right) /\left(16.205+x^{\wedge} 2.277\right)$ & 15 & 835.43 \\
\hline & & & 16 & 865.25 \\
\hline & & & 17 & 891.70 \\
\hline & & & 18 & 915.21 \\
\hline & & & 19 & 936.14 \\
\hline & & & & 954.82 \\
\hline \multirow{11}{*}{$\begin{array}{l}\text { Terminalia } \\
\text { bellerica }+ \\
\text { soybean }\end{array}$} & MMF & $\mathrm{y}=\left(49.749 * 34.045+1052.29 * x^{\wedge} 2.169\right) /\left(34.045+x^{\wedge} 2.169\right)$ & 15 & 964.68 \\
\hline & & & 16 & 975.25 \\
\hline & & & 17 & 984.10 \\
\hline & & & 18 & 991.57 \\
\hline & & & 19 & 997.57 \\
\hline & & & 20 & 1003.3 \\
\hline & Weibull & $\mathrm{y}=962.32-953.75 * \exp \left(-0.0663 * x^{\wedge} 1.5483\right)$ & 15 & 950.49 \\
\hline & Model & & 16 & 954.86 \\
\hline & & & 17 & 957.69 \\
\hline & & & 18 & 959.49 \\
\hline & & & $\begin{array}{l}19 \\
20\end{array}$ & $\begin{array}{l}960.62 \\
961.31\end{array}$ \\
\hline \multirow{11}{*}{$\begin{array}{l}\text { Mangifera } \\
\text { indica+ } \\
\text { soybean }\end{array}$} & MMF & $\mathrm{y}=\left(37.075 * 252.09+784.84 * x^{\wedge} 2.735\right) /\left(252.094+x^{\wedge} 2.735\right)$ & 15 & 685.56 \\
\hline & & & 16 & 699.80 \\
\hline & & & 17 & 711.52 \\
\hline & & & 18 & 721.23 \\
\hline & & & $\begin{array}{l}19 \\
20\end{array}$ & $\begin{array}{l}729.32 \\
736.12\end{array}$ \\
\hline & Polynomi & $y=31.809-5.310 x+11.294 x^{\wedge} 2-0.554 x^{\wedge} 3$ & 15 & 602.60 \\
\hline & al Model & & 16 & 637.11 \\
\hline & & & 17 & 654.33 \\
\hline & & & 18 & 650.92 \\
\hline & & & 19 & 623.56 \\
\hline & & & 20 & 630.05 \\
\hline
\end{tabular}


Table.4 Table shows the best suited models with their predicted yield values of soybean at one meter distance from the tree for next 6 years and the corresponding increment values


\begin{tabular}{|l|l|}
\hline 15 & 0.479 \\
\hline 16 & 0.275 \\
\hline 17 & 0.136 \\
\hline 18 & 0.039 \\
19 & 0.029 \\
\hline 20 & 0.078 \\
\hline & \\
15 & 4.993 \\
16 & 8.463 \\
17 & 11.71 \\
18 & 13.92 \\
19 & 14.52 \\
\hline 20 & 13.37 \\
\hline
\end{tabular}

Terminalia
bellerica+
soybean

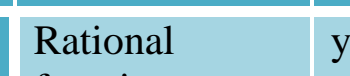

$y=7.596+6.951 * \cos (0.508 x-3.3055)$

function



15

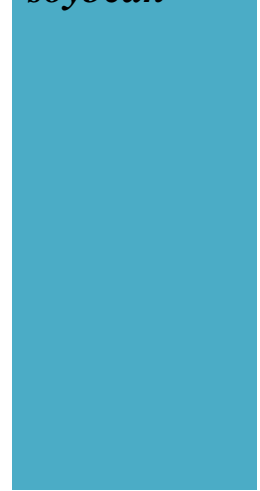

\section{Mangifera} indica+

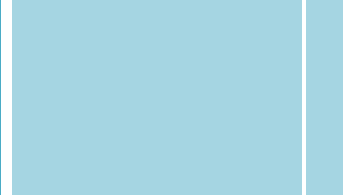

$18 \quad 2.080$

$19 \quad 1.935$

$20 \quad 1.808$

soybean

\begin{tabular}{|c|c|c|c|}
\hline Hoerl model & $y=3.612^{*}\left(0.558^{\wedge} x\right) *\left(x^{\wedge} 2.646\right)$ & $\begin{array}{l}15 \\
16 \\
17 \\
18 \\
19 \\
20\end{array}$ & $\begin{array}{l}0.728 \\
0.481 \\
1.315 \\
0.204 \\
0.131 \\
0.084\end{array}$ \\
\hline Hoerl model & $y=2.13^{*}\left(0.527^{\wedge} x\right)^{*}\left(x^{\wedge} 3.383\right)$ & $\begin{array}{l}15 \\
16 \\
17 \\
18 \\
19 \\
20\end{array}$ & $\begin{array}{l}1.366 \\
0.895 \\
0.579 \\
0.370 \\
0.234 \\
0.146\end{array}$ \\
\hline $\begin{array}{l}\text { Rational } \\
\text { function }\end{array}$ & $y=(2.030+0.684 x) /\left(1-0.308 x+0.031 x^{2}\right)$ & $\begin{array}{l}15 \\
16 \\
17 \\
18 \\
19 \\
20\end{array}$ & $\begin{array}{l}3.462 \\
3.066 \\
2.745 \\
2.480 \\
2.258 \\
2.069\end{array}$ \\
\hline
\end{tabular}

In case on Ceiba pentandra + soybean, the best selected models are Gompertz and MMF model. In case of Gompertz model, the increment seen in height between $15^{\text {th }}$ to $20^{\text {th }}$ year ranges between $823.74 \mathrm{~cm}$ to $903.61 \mathrm{~cm}$, whereas in case of MMF model it ranges between 
$835.43 \mathrm{~cm}$ to $954.82 \mathrm{~cm}$. In case on Terminalia bellerica+ soybean, the best selected models are MMF and Weibull model. In case of MMF model, the increment seen in height between $15^{\text {th }}$ to $20^{\text {th }}$ year ranges between $964.68 \mathrm{~cm}$ to $1003.3 \mathrm{~cm}$, whereas in case of Weibull model it ranges between $950.49 \mathrm{~cm}$ to $961.31 \mathrm{~cm}$.

In case on Mangifera indica + soybean, the best selected models are MMF and Polynomial model. In case of MMF model, the increment seen in height between $15^{\text {th }}$ and $20^{\text {th }}$ year ranges between $685.56 \mathrm{~cm}$ and $736.12 \mathrm{~cm}$, whereas in case of Polynomial model it ranges between and $602.60 \mathrm{~cm}$ and $623.56 \mathrm{~cm}$ (Table 3 ).

Best suited models with their predicted yield values of soybean for next 6 years and the corresponding decreased values at one meter distance from the trees.

In case on Ceiba pentandra + soybean, the best selected models are Rational function and Sinusoidal model. In case of Rational function the decline as been seen in yield between $15^{\text {th }}$ to $20^{\text {th }}$ year ranges between $0.479(\mathrm{~kg} / \mathrm{ha})$ to $0.0783(\mathrm{~kg} / \mathrm{ha})$. Whereas in case of Sinusoidal model $4.993(\mathrm{~kg} / \mathrm{ha})$ to $13.37(\mathrm{~kg} / \mathrm{ha})$.

In case on Terminalia bellerica+ soybean, the best selected models are Rational function and Hoerl model. In case of Rational function, the decline as been seen in yield between $15^{\text {th }}$ to $20^{\text {th }}$ year ranges between $2.679(\mathrm{~kg} / \mathrm{ha})$ to $1.808(\mathrm{~kg} / \mathrm{ha})$. Whereas in case of Hoerl model $0.728(\mathrm{~kg} / \mathrm{ha})$ to $0.084(\mathrm{~kg} / \mathrm{ha})$. In case on Mangifera indica+ soybean, the best selected models are Hoerl model and Rational function. In case of Hoerl model the decline as been seen in yield between $15^{\text {th }}$ and $20^{\text {th }}$ year ranges between $1.366(\mathrm{~kg} / \mathrm{ha})$ and $0.146 \quad(\mathrm{~kg} / \mathrm{ha})$.
Whereas in case of Rational function $3.462(\mathrm{~kg} / \mathrm{ha})$ to 2.069 (kg/ha) (Table 4).

\section{References}

Ajit Srivastava, P. N., Gupta, V. K. and Solanki, K. R. 2007b, Linear tree growth models: A limitation of negative estimation of size. Indian Forester. 126(12): 1336-1341.

Carus, S. and Cicek, E., 2007, Growth and yield prediction models for ash (Fraxinus anguistifolia Vahl) plantations in Turkey. J. Applied Biological Sci., 1(1): 13-18.

Korwar, G.M., 1992, Studies on alley cropping and agro-silviculture system in black soils under dryland agricultural conditions. Ph.D. Thesis, University of Agricultural Sciences, Dharwad.

Mohammed Afzal, M. and Hafeez, 1999, Effect of forest and fruit trees on wheat crop. Pakistan J. For., 47(1): 47-57.

Newaz. M.S. and Millat-e-Mustafa, M., 2004, Growth and Yield prediction models for Acacia mangium grown in the plantations of the central region of Bangladesh. New For., 27(1): 81-88.

Rahaman, M.M. and Ahmad, L.V., 2000, Growth and yield prediction model of Jamoon (Gmelina arbonea) in Chittagong hill tracts of Bangladesh. J. Tropical For. Sci., 12(2): 276-285.

Raizada, A., Rao, M.S.R.M., Nambiar, K.T.N. and Padmaiah, H., 2007, Bio-mass production and prediction models for Acacia nilotica in salt affected vertisols in Karnataka. Indian For., 133(2): 239-246.

Thakur, T. and Singh, L., 2005, Growth and above ground biomass in short rotation Eucalyptus tereticornis Sm. provenances. Plant Archives, 5 (2): 441-445.

\section{How to cite this article:}

Veena, R., S.N. Megeri and Patil, S.J. 2018. Statistical Models to Predict the Height of Trees and Yield of Field Crop in the Agroforestry System. Int.J.Curr.Microbiol.App.Sci. 7(09): 3345-3351. doi: https://doi.org/10.20546/ijcmas.2018.709.415 